\title{
Analisis Evaluasi Lokasi Penempatan Gardu Induk yang Optimal dengan Mempertimbangkan Atribut dan Interaksi Spasial
}

\author{
Wahyu Surya Putra Pradana \\ Assistant Engineer Instrument \& Control PT.PJB UP Muara Tawar \\ wahyusuryaputrapradana@yahoo.co.id
}

\begin{abstract}
Abstrak
Prediksi beban listrik memiliki hubungan yang erat dengan penempatan dan pengembangan gardu induk sebagai langkah balancing load capacity. Diperlukan prediksi konsumsi beban listrik secara tepat untuk dapat memberikan rekomendasi penempatan gardu induk sesuai pusat beban yang ada. Salah satu langkah awal adalah dengan mempertimbangkan analisis komponen spasial dalam peramalannya. Pada penelitian ini, pusat beban; topografi; demografi; geologi serta peta seismotektonik akan menjadi variabel atribut yang diolah dalam analisis peramalan spasial. Dengan adanya area pengelompokan pusat beban menurut tingkat konsumsi listrik masa depannya maka dapat dilakukan evaluasi penempatan gardu induk disesuaikan dengan kondisi konsumsi masing-masing daerah amatan. Untuk pengoptimalan penempatan gardu induk yang dilakukan, Rencana Tata Ruang Wilayah (RTRW) juga menjadi hal yang harus dipertimbangkan. Langkah tersebut dilakukan sebagai bentuk langkah strategik perusahaan dalam menyikapi dinamika ketidakpastian beban. Sehingga dalam penelitian ini, peneliti bertujuan untuk menganalisis lokasi penempatan gardu induk yang optimal dengan mempertimbangkan atribut dan interaksi spasial yang mengacu pada pusat beban /konsumsi beban listrik masa depan yang dilakukan dengan menggunakan metode Spatial Multicriteria Decision Analysis melalui perantara software ArcGIS (Geographic Information System). Pemilihan lokasi berdasarkan prinsip kriteria kecocokan menggunakan metode WLC (Weighted Linier Combination). Sedangkan untuk peringkat skor dan pembobotan faktor pada peta dianalisis dengan AHP (Analytic Hierarchy Process). Peta gabungan yang berisi prioritas lokasi potensial akan diwakili oleh beberapa poligon yang diperoleh dari analisis spatial MCDA pada software ArcGIS 10.1. Beberapa lokasi gardu induk yang optimal di area Jawa Timur dipilih sebagai lokasi kandidat setelah menghilangkan lokasi dengan nilai terendah melalui AHP pada software Expert Choice. Lokasi-lokasi tersebut di rangking untuk mendapatkan lokasi yang diinginkan.
\end{abstract}

Kata kunci: atribut \& interaksi spasial, Spatial MultiCriteriaDecision Analysis, GIS dan gardu induk.

\section{PENDAHULUAN}

Dalam langkah mendukung kebijakan pemerintah “35.000 MW untuk Indonesia”, diperlukan adanya pengembangan kapasitas pembangkit untuk memperluas tercapainya pasokan energi. Salah satu langkah pendukung tersebut adalah proses pemilihan lokasi pembangkit dan gardu induk. Proses pemilihan lokasi dimaksudkan untuk mengidentifikasi lokasi potensial. Penempatan/pemilihan merupakan proses pemilihan lokasi yang sesuai dengan fasilitas pembangkit, termasuk pengkajian yang tepat dari sisi finansial dan memerlukan metode penilaian komparatif yang memperhitungkan kriteria penolakan dan penerimaan dalam pedoman peraturan setempat[1]

\section{TUJUAN}

Tujuan dari penelitian ini adalah untuk memberikan rekomendasi dan evaluasi pada lokasi gardu induk berdasarkan metode Spatial Multi-criteria Decision Analysis yang digunakan. Lokasi-lokasi dari hasil analisis tersebut dapat dianggap paling sesuai untuk lokasi penempatan gardu induk di area Jawa Timur sebagai objek amatan. Penelitian dilakukan berdasar informasi dan data yang didapatkan dari berbagai sumber serta pengamatan peta.

\section{PENGUMPULAN DATA}

Data yang tersedia didapatkan dari acuan penelitian sebelumnya dan sumber-sumber data publik dari lembaga terkait. Data-data yang digunakan meliputi konsumsi kWh listrik; topografi; geologi; peta seismotektonik [2], [3]; demografi; pertumbuhan pemukiman dan industri. Disertakan pula data Rencana Tata Ruang Wilayah (RTRW) sebagai bahan pertimbangan tambahan.

\section{METODOLOGI PEMILIHAN LOKASI}

Ada beberapa langkah sebagai acuan proses pemilihan lokasi seperti yang dijelaskan di [1]yang dapat digunakan untuk proses evaluasi lokasi gardu induk. Tahap I yaitu analisis regional, tahap II meliputi screening dan membandingkan lokasi potensial, tahap III merupakan screening, membandingkan dan memberi peringkat untuk kandidat lokasi yang sesuai. 
Untuk mendukung tercapainya tujuan paper ini, maka penulis menggunakan metode Spatial Multi Criteria Decision Analysis dipadukan dengan 3 metode[3] yang nantinya diolah di dalam software ArcGIS 10.1. Metode tersebut meliputi : Binary Overly, WLC (Weighted Linear Combination) dan metode AHP (Analytic Hierarchy Process). Gambar 1 dibawah ini menunjukkan alur proses pengambilan keputusan untuk menentukan pemilihan lokasi gardu induk pada penelitian ini.

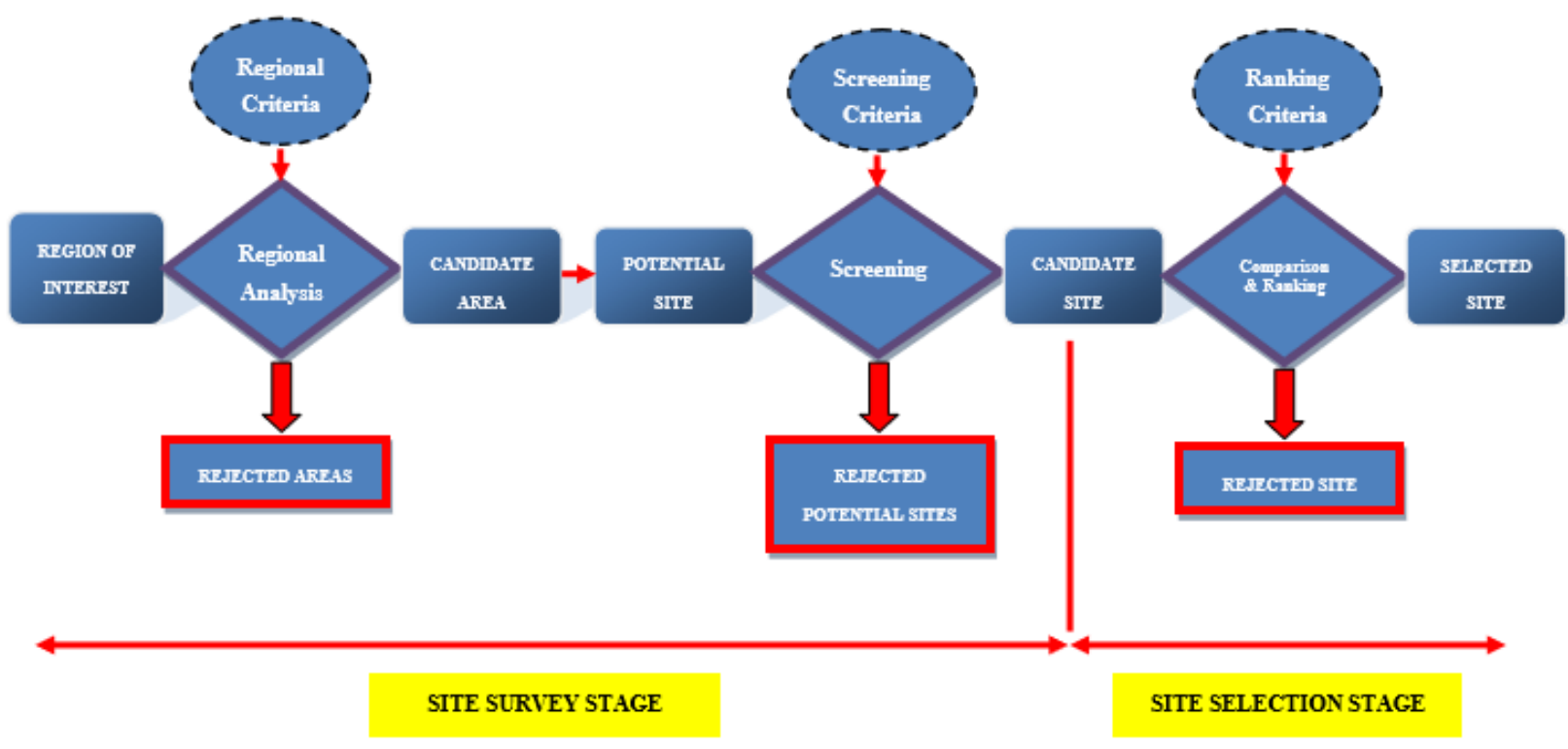

Gambar 1. Diagram proses pemilihan lokasi [1]

Dalam beberapa penelitian terdahulu banyak digunakan metode pendekatan Saaty (AHP) sebagai alat pendukung keputusan untuk menyelesaikan permasalahan keputusan yang kompleks. AHP menggunakan struktur hierarki multi level objective, kriteria, sub kriteria dan alternatif. Metode AHP sering digunakan dalam kombinasinya dengan GIS untuk memvisualkan area yang tepat/cocok[4]. Sebanyak 8 atribut yang berhubungan dengan lingkungan, sosial, dan industri digunakan dalam penelitian ini sebagai bahan pertimbangan yang akan dimasukkan dalam analisis di ArcGIS dan AHP. Dikarenakan penelitian yang melibatkan objek gardu induk masih belum banyak, maka penelitian ini mengacu pada analisis pemilihan lokasi untuk pembangkit listrik.

\subsection{GIS dan Multi-criteria Decision Analysis}

Multi-criteria Decision Analysis (MCDA) merupakan analisis keputusan multi kriteria yang berasal pada awal 1960-an. Analisis keputusan multi kriteria berbasis GIS dapat dianggap sebagai proses yang menggabungkan dan mengubah data spasial menjadi sebuah hasil keputusan. Dalam spasial MCDA terdapat dua pertimbangan penting untuk proses analisisnya yaitu kemampuan GIS dalam pengambil alihan data, penyimpanan, pencarian, manipulasi dan analisis serta kemampuan MCDM untuk menggabungkan data geografis dan preferensi pengambil keputusan menjadi satu nilai keputusan alternatif [5]. Untuk kasus pembangkit listrik, GIS berbasis pendekatan MCDA dapat digambarkan sebagai proses yang menggabungkan dan mengubah sekumpulan data secara spasial menjadi sebuah output peta [6]. Dalam penelitian ini, terdapat beberapa langkah dimana kriteria keputusan dapat dikombinasikan dengan MCDA yaitu:

\subsection{Metode Binary Overly}

Metode ini menggunakan sepenuhnya analisis yang terdapat pada software ArcGIS. Metode ini digunakan untuk menentukan area lokasi potensial menggunakan 5 konstrain/kendala dalam penelitian ini. Pada intinya, metode ini akan mengidentifikasi dan mengelompokkan area dengan membagi data di setiap area tersebut. Area-area yang memenuhi nilai konstrain terendah akan menjadi area yang dipilih untuk lokasi penempatan gardu induk. Daerah yang memenuhi kriteria dan tidak memenuhi kriteria dibedakan, dan pada akhirnya daerah yang memenuhi kriteria akan menjadi peta kandidat akhir. Logika AND dan OR akan digunakan dalam proses analisis metode ini. Pada penggunaan logika OR, hanya dibutuhkan satu nilai sel yang berkategori baik untuk dimasukkan dalam daftar lokasi yang dipilih. Sedangkan logika AND hanya membutuhkan satu nilai sel yang berkategori buruk untuk mengeliminasi lokasi tersebut [3].

\subsection{Weighted Linear Combination}

Metode WLC mengasumsikan bahwa bobot setiap faktor tidak sama. Berikut merupakan persamaan dari metode WLC:

$Z(i, j)=\sum_{k=1}^{n} w_{k} y_{k}(i, j)$ dimana $\sum_{k=1}^{n} w_{k}=1$

$\mathrm{Z}(\mathrm{i}, \mathrm{j})$ merupakan nilai kerawanan akhir dari piksel $(\mathrm{i}, \mathrm{j})$ dan $\mathrm{w}_{\mathrm{k}}$ adalah bobot kombinasi linear untuk faktor ke-k. Dalam proses ini, terdapat hal yang dapat membedakan antara metode Boolean Combination dengan WLC. Boolean combination menentukan derajat ketersediaan dengan logika boolean dimana setiap faktor ditetapkan dengan kriteria seusai dan tidak sesuai. Sedangkan WLC mengasumsikan bahwa derajat kesesuaian tidak hanya 2 kriteria sesuai dan tidak sesuai, tetapi

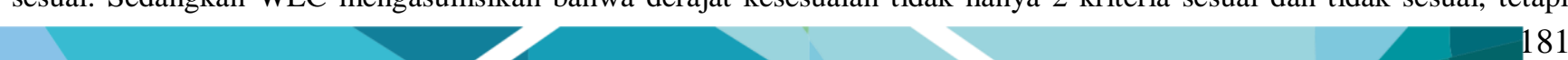


membagi kriteria dengan pendekatan faktor pendukung diberi derajat nilai lebih dari dua (misalnya pada skala 1-5 atau 1-9) dan faktor kendala dengan derajat nilai mengikuti logika boolean.

\subsection{Analytic Hierarchy Process (AHP)}

AHP merupakan metode untuk mengukur derajat kepentingan antar faktor dengan meminta pendapat ahli. Konsistensi jawaban diukur dengan logika transitif dimana faktor xi dinilai lebih penting dari x2 dan x2 lebih penting dari x3, maka x1 harus lebih penting dari x3. Ukuran konsistensi dihitung dengan persamaan berikut [7]:

$$
C I=\frac{\lambda_{\max }-n}{n-1} \text { dan } C R=\frac{C I}{R I}
$$

Dimana CI = indeks konsistensi, = nilai eigen terbesar dari matriks orde $\mathrm{n}, \mathrm{n}=$ jumlah faktor, $\mathrm{CR}=$ rasio inkonsistensi, $\mathrm{RI}=$ nilai pembangkit random. Bila $\mathrm{CI}=$ nol berarti matriks konsisten. Ukuran inkonsistensi dilihat dari nilai $\mathrm{CR}$, jika $\mathrm{CR}<$ $10 \%$ maka inkonsistensi yang terjadi dianggap masih dapat diterima.

\section{KRITERIA PEMILIHAN LOKASI GARDU INDUK}

Kriteria mendefinisikan sebuah tingkat kebutuhan dari pencapaian masing-masing pertimbangan yang dibangun untuk mengidentifkasi area sebagai langkah evaluasi lebih jauh. Terdapat dua tipe kriteria yang digunakan dalam proses pemilihan lokasi, kriteria-kriteria tersebut didefinisikan berdasar keragaman konstrain/kendala yang ditemukan. Adapun kriteria tersebut adalah:

5.1. Konstrain/kendala (criteria yang ditolak)

1. Peta Taman Nasional Jawa Timur.

2. Peta daerah yang mengandung habitat ekologi sensitif dan penting (lahan kritis).

3. Peta daerah dengan pusat populasi besar.

4. Peta potensi pergeseran patahan lempeng bumi.

5. Peta daerah sumber air bersih.

Sedangkan untuk kriteria yang cocok (sesuai) meliputi faktor yang memiliki pengaruh terbesar untuk proses pemilihan lokasi:

1. Peta area yang dekat dengan pusat beban. Kedekatan dengan pusat beban (populasi besar \& industri padat energi) untuk meminimalkan biaya transmisi serta kerugian daya.

2. Peta seismik. Area dengan tingkat resiko gempa yang kecil akan menjadi prioritas pemilihan lokasi. Selain itu, daerah yang memiliki tingkat keparahan dampak banjir yang kecil menjadi kriteria yang dapat diterima.

3. Peta Penggunaan Lahan.

- Area Eksplorasi. Daerah yang memiliki jarak yang cukup jauh dari dari area eksplorasi mineral, minyak, dan gas menjadi kriteria yang dapat diterima.

- Lokasi Pemukiman. Lokasi yang berada di luar area pemukiman menjadi prioritas.

- Situs Sejarah. Lokasi yang jauh dari situs bersejarah juga merupakan kriteria yang feasible

4. Peta Topografi. Topografi daerah yang datar merupakan keuntungan dari sudut pandang pemilihan lokasi gardu induk. Daerah tebing dan gunung menjadi kriteria yang harus ditolak.

5. Peta Transportasi. Peta kedekatan dengan sarana transnportasi seperti jalan raya akan menjadi prioritas dikarenakan untuk akses pembangunan dan pemeliharaan.
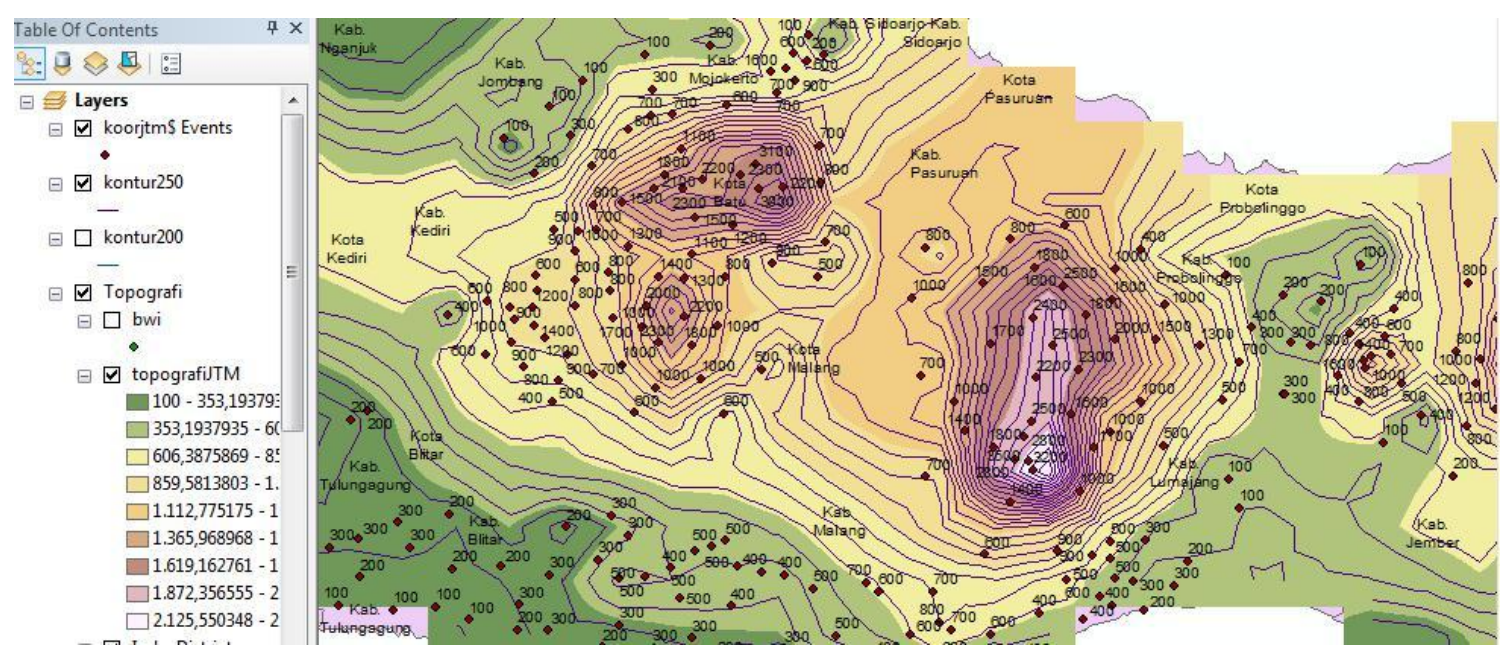

Gambar 2. Peta kontur Jatim 


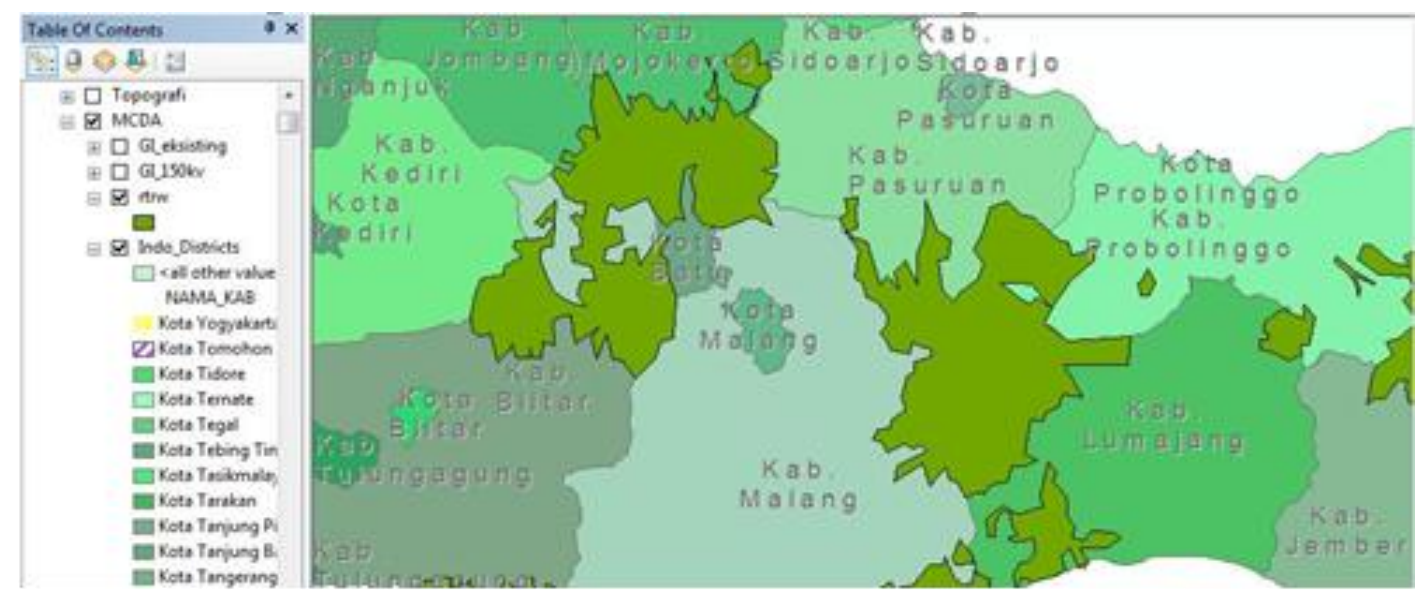

Gambar 3. Peta Hutan Lindung Jatim

\section{ANALISIS}

1. Analisis Regional

Analisis regional (daerah) untuk proses penentuan lokasi didasarkan pada filosofi kriteria konstrain (kendala) yang terdiri dari 5 konstrain. Untuk analisis model pertama adalah Binary Overly menggunakan pendekatan Risk Low dimana operator logika OR digunakan untuk menentukan hasil dari kombinasi (daerah kandidat) setelah menghilangkan daerah yang tidak memenuhi kriteria (kriteria yang ditolak). Analisis penghilangan konstrain dilakukan di software ArcGIS 10.1.

\section{Analisis screening \& ranking lokasi yang potensial}

Metode WLC dan AHP digunakan dalam proses kedua ini. Untuk mengevaluasi kesesuaian setiap alternatif, setiap kriteria dievaluasi secara independen. Daerah kandidat diperoleh setelah menghilangkan daerah yang tidak mencapai kriteria yang feasible bagi lokasi gardu induk (5 konstrain) menggunakan logika OR. Screening dan rangking lokasi potensial didasarkan pada penggunaan kriteria kesesuaian dan metode WLC. 5 kriteria yang feasible tersebut diubah ke dalam peta dengan nilai skor 0-1. Pairwise comparison dilakukan dan skor relatif dimasukkan ke dalam software Expert Choice. Proses ini menghasilkan skor yang digunakan dalam peta kriteria yang feasible disertai dengan nilai pembobotannya. Pembobotan faktor dan skor yang diperoleh dengan menggunakan metode AHP pada software Expert Choice kemudian diimport ke tool MCDA di ArcGIS 10.1. Prioritas lokasi potensial diperoleh dengan menggunakan metode WLC.

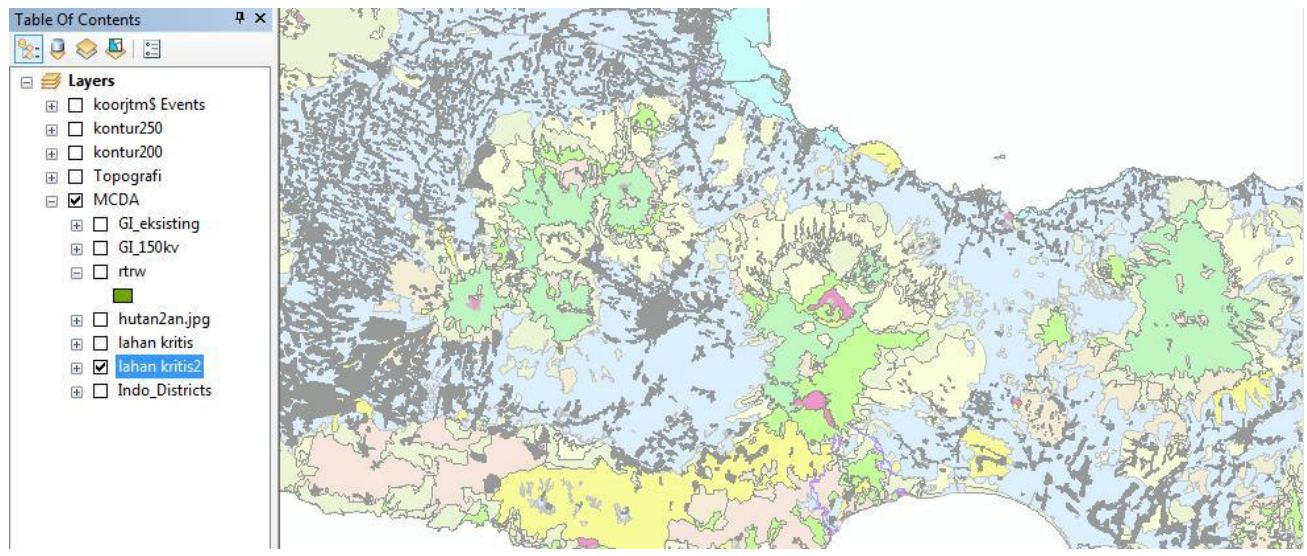

Gambar 4. Peta Lahan kritis Jatim

3. Screening, membandingkan dan memberi peringkat untuk kandidat lokasi yang sesuai.

Metode AHP digunakan untuk analisis ranking dan membandingkan kandidat lokasi untuk memilih lokasi yang sesuai dengan kriteria penempatan gardu induk. Delapan faktor kesesuaian (kriteria kecocokan) digunakan untuk me-rangking dan perbandingan. Bobot dan skor (eigenvector) dari kriteria dan lokasi diperoleh dengan perbandingan berpasangan antara atribut dan antar lokasi dengan memperhatikan setiap kriteria. Software expert choice digunakan untuk memecahkan problem matriks dari peta gabungan kriteria yang ditolak dan kriteria kecocokan. 


\section{KESIMPULAN}

Terdapat tiga tahap/proses untuk melakukan analisis pemilihan lokasi penempatan gardu induk. Pada langkah I, metode binary overly dengan menggunakan prinsip logika OR untuk memilih daerah kandidat. Selanjutnya diteruskan dengan metode WLC \& AHP yang digunakan untuk menyaring dan memilih lokasi potensial dengan bantuan software ArcGIS 10.1. Delapan faktor yang berhubungan dengan seismic, penggunaan lahan, topografi, kedekatan denga pusat beban, kedekatan dengan jalur transportasi diwakili dalam bentuk peta. Skor relatif dan pembobotan diturunkan dari metode AHP.

\section{DAFTAR PUSTAKA}

[1] IAEA, Safety Aspects in Sitting for Nuclear Installations. Vienna: IAEA, 2011.

[2] USGS, "Using the USGS Landsat 8 Product," 2003. [Online]. Available: http://landsat.usgs.gov/Landsat8_Using_Product.php.

[3] F. A. . Abudeif A.M., Moneim A., "Multicriteria decision analysis based on analytic hierarchy process in GIS environment for sitting nuclear power plant in Egypt," Ann. Nucl. Energy, vol. 75, pp. 682-692, 2015.

[4] G. A. Charabi Y, "PV site suitability analysis using GIS-based spatial fuzzy multi-criteria evaluation," Renew Energy, vol. 36, pp. 2554-2561, 2011.

[5] Malczewski J., GIS and Multi-criteria decision analysis. New York: John Wiley \& Sons, 1999.

[6] W. C. Olufemi A., Brandon R., "Adapting a GIS-based multicriteria decision analysis approach for evaluating new power generating sites," Appl. Energy, vol. 96, pp. 292-301, 2012.

[7] T. L. Saaty, Fundamentals of analytic hierarchy process. Pittsburgh: RWS Publication, 1994. 